\title{
Chemical and bacteriological analysis of the water from drinking fountains located in
} a Higher Education Institution

\author{
Análise química e bacteriológica da água dos bebedouros localizados em uma Instituição de Ensino
} Superior

Análisis químico y bacteriológico del agua de los bebederos ubicados en un Instituto de Educación Superior

Received: 01/19/2021 | Reviewed: 01/23/2021 | Accept: 01/28/2021 | Published: 02/04/2021

\author{
Josidel Conceição Oliver \\ ORCID: https://orcid.org/0000-0002-8381-8742 \\ Universidade Federal de Alfenas, Brazil \\ E-mail: jsdl.oliver@gmail.com \\ Ramon Alves de Oliveira Paula \\ ORCID: https://orcid.org/0000-0002-4562-0970 \\ Universidade Federal de Minas Gerais, Brazil \\ E-mail: alvesfarmacia@yahoo.com.br \\ Sandra Maria Oliveira Morais Veiga \\ ORCID: https://orcid.org/0000-0002-0956-9936 \\ Universidade Federal de Alfenas, Brazil \\ E-mail: smveiga @ gmail.com
}

\begin{abstract}
The aim of this study was to evaluate, through chemical and bacteriological parameters, the water quality from drinking fountains at a Federal Higher Education Institution, in different climatic periods. Total coliforms and Escherichia coli were quantified by the enzyme method of the defined substrate; heterotrophic bacteria by plating in depth in Plate Count Agar; $\mathrm{pH}$ and chlorine, using commercial kits. The research was conducted in two stages: the first one, referring to the initial analyses during the rainy season, with the verification of the presence of samples in disagreement with the current legislation; and the second, during the dry period, after the corrective measures adopted in function the results obtained in the first stage, totalling 89 samples in both stages, from 49 drinking fountains. In the first stage, bacteriological evaluations showed that $65.3 \%$ of the samples were inadequate, while in the second, the failure rate was $20.4 \%$. The parameters evaluated in the two stages revealed that there was no significant result ( $>>0.05)$ in relation to $\mathrm{pH}$, total coliforms and Escherichia coli. Unlike what was observed for mesophilic aerobic and chlorine content $(\mathrm{p}<0.05)$, which are believed to have been influenced by climatic conditions, with higher rates of non-compliance in the first stage, that is, found in the rainy season. These findings demonstrate the existence of inadequate hygienic-sanitary conditions and the need of frequent monitoring of water quality, as well as the positive impact after the educational intervention and the adoption of preventive and corrective measures, aimed at the safety of the consumer community.
\end{abstract}

Keywords: Drinking water; Water analysis; Control of water quality.

\begin{abstract}
Resumo
O objetivo deste estudo foi avaliar, por meio de parâmetros químicos e bacteriológicos, a qualidade da água dos bebedouros de uma Instituição Federal de Ensino Superior, em diferentes períodos climáticos. Coliformes totais e Escherichia coli foram quantificados pelo método enzimático do substrato definido; bactérias heterotróficas por plaqueamento em profundidade em Ágar Padrão para Contagem; $\mathrm{pH}$ e o cloro, mediante kits comerciais. A pesquisa foi conduzida em duas etapas: a primeira, referente às análises iniciais durante o período chuvoso, com a constatação da presença de amostras em desacordo com a legislação vigente; e a segunda, no decorrer do período seco, após as medidas corretivas adotadas em função dos resultados obtidos na primeira etapa, totalizando 89 amostras nas duas etapas, provenientes de 49 bebedouros. Na primeira etapa, as avaliações bacteriológicas mostraram que $65,3 \%$ das amostras estavam inadequadas, enquanto na segunda, a porcentagem de reprovação foi de $20,4 \%$. Os parâmetros avaliados nas duas etapas revelaram que não houve resultado significativo $(\mathrm{p}>0,05)$ em relação ao $\mathrm{pH}$, coliformes totais e Escherichia coli. Diferentemente do observado para os aeróbios mesófilos e o teor de cloro ( $<<0,05)$, os quais acredita-se que foram influenciados pelas condições climáticas, com maiores índices de não conformidade na primeira etapa, ou seja, no período chuvoso. Estas constatações demonstram a existência de condições higiênico-sanitárias inadequadas e a necessidade de monitoramento frequente da qualidade da água, bem como o impacto positivo após a
\end{abstract}


intervenção educativa e da adoção de medidas preventivas e corretivas, visando a segurança da comunidade consumidora.

Palavras-chave: Água potável; Análise da água; Controle da qualidade da água.

\section{Resumen}

El objetivo de este estudio fue evaluar, a través de parámetros químicos y bacteriológicos, la calidad del agua de los bebederos de un Instituto Federal de Educación Superior, en diferentes períodos climáticos. Los coliformes totales y Escherichia coli se cuantificaron mediante el método enzimático de sustrato definido; las bacterias heterótrofas por siembra profunda en agar estándar para recuento; mientras que el pH y el cloro se determinaron utilizando kits comerciales. La investigación se llevó a cabo en dos etapas: la primera, correspondiente a los análisis iniciales durante la época de lluvias, donde se verificó la presencia de muestras en desacuerdo con la legislación vigente; y la segunda, durante el periodo seco, luego de adoptar las medidas correctivas en función de los resultados obtenidos en la primera etapa, totalizando 89 muestras en las dos etapas, provenientes de 49 bebedores. En la primera etapa, las evaluaciones bacteriológicas revelaron que el $65.3 \%$ de las muestras eran inconformes, mientras que en la segunda la tasa de reprobación fue del $20.4 \%$. Los parámetros evaluados en ambas etapas revelaron que no hubo diferencia significativa $(\mathrm{p}>0.05)$ con relación al $\mathrm{pH}$, coliformes totales y Escherichia coli. A diferencia de lo observado para los aerobios mesófilos y el contenido de cloro $(\mathrm{p}<0,05)$, que se estima fueron influenciados por las condiciones climáticas, presentando mayores tasas de inconformidad durante la primera etapa, es decir, durante la temporada de lluvias. Estos hallazgos demuestran la existencia de condiciones higiénico-sanitarias inadecuadas y la necesidad de un monitoreo frecuente de la calidad del agua, así como el impacto positivo tras la intervención educativa y la adopción de medidas preventivas y correctivas, orientadas a la seguridad de los consumidores.

Palabras clave: Agua potable; Análisis de agua; Control de calidad del agua.

\section{Introduction}

Water is an indispensable element of life, being the main component of the human body, corresponding to approximately $70 \%$ of body weight. As a good solvent, it can carry chemical residues, microorganisms and parasites, compromising its quality and representing a potential risk to population health, if it does not have potability characteristics (Antunes, Castro, \& Guarda, 2004; Schazmann, Menoncin, Elpo, \& Gomes, 2008).

It is considered as drinking water or water for human consumption, the water that is purposed to be ingested, used in the preparation and production of food and for personal hygiene (Brazil, 2017). In Brazil, in order to be considered drinkable, water must follow the standards established by the legislation, represented by Normative Ordinance $n^{\circ} .5$ of 2017 annex XX of the Ministry of Health (Brazil, 2017). So, it should be subject to quality control and surveillance and must fit the microbiological parameters, which aims to investigate, identify and quantify bacteria indicators, in addition to the physicochemical ones, that aims to detect toxic substances (Brazil, 2017; Pongeluppe et al., 2009).

Contamination of water with pathogens may occur from direct pollution in its sources or even after treatment and distribution, if the reservoirs, filters or faucets are in poor hygienic conditions and conservation (Michelina, Bronharoa, Daréb, $\&$ Ponsanoc, 2006). In this context, drinking fountains are also considered as potential sources of contamination, since they are used by a huge number of individuals about whom hygiene habits are unknown (Araújo, Baraúna, \& Meneses, 2009).

Starting from the premise of drinking water quality as a public health issue and that climatic condition can influence the levels of its contamination (Bunyavanich, Landrigan, McMichael, \& Epstein, 2003; Castro et al., 2016), it is worrying the scarcity of information about the theme, particularly in health and educational institutions. In these environments, effective control of its potability is extremely important.

Thus, the present study aimed to analyze the chemical and bacteriological parameters in water samples from drinking fountains at a Federal Institution of Higher Education, in different climatic periods, evaluating drinking parameters and their implications for consumers' health. 


\section{Methodology}

The chemical and bacteriological quality of the water from 49 drinking fountains at Federal University of Alfenas (Unifal-MG), in Alfenas-MG (main campus), were analyzed. Samples were collected aseptically, from 01 to 49. The research was carried out during the academic period of the university community in two different phases, the first between the months of February and March (rainy season) and the second from August to September (dry season), thus totaling 98 samples collected. Thus, it can be observed the possibility of seasonal variations in water quality and the impact of educational intervention and the adoption of corrective measures through the detection of hygienic-sanitary non-compliance.

In view of the large number of non-compliant samples were obtained in relation to the legal requirements (first stage), the responsible for the general services of the Institution was informed about these results, advising on the correct hygiene of the drinking fountains, that is, cleaning with water, soap and $70 \%$ alcohol. In addition, it was suggested the change of filters of some equipment and the cleaning of the reservoirs (water tank).

To collect the samples, the water dispersing spray were sanitized with the aid of tweezers and a cotton swab soaked in $70 \%$ alcohol and then flambéed with the cotton wool on fire. The water was allowed to flow for three minutes in an aseptic field (presence of flame) and after this period the samples were collected in sterile plastic bottles of $100 \mathrm{~mL}$ capacity, containing sodium thiosulfate $\left(\mathrm{Na}_{2} \mathrm{~S}_{2} \mathrm{O}_{3}\right)$ to neutralize the residual chlorine in the water. After this procedure, the bottles were conditioned in isothermal (Styrofoam and ice) boxes for rapid transportation to the Food Microbiology Laboratory at UNIFAL-MG. Before completing the sampling procedure, analysis were performed to determine the $\mathrm{pH}$ and residual chlorine "in locus".

Residual chlorine and $\mathrm{pH}$ were determined by semi-quantitative colorimetric methodology using MQuant ${ }^{\circledR}$ reagent and strips kits (Merck) according to the manufacturer's instructions and similar to the methodology used by Andrade et al. (2016) and Schwenke et al. (2019). Chlorine analysis was performed using the DPD (diethyl-p-phenylenediamine) method which in contact with water without iodide (weakly acidic solution) oxidizes and acquires a red-violet color. Thus, the intensity of this color is proportional to the concentration of free chlorine, which is measured by visual comparison between the color of the sample and a color scale (Helbling \& VanBriesen, 2007; Soares et al., 2016).

In the laboratory, counts of mesophilic aerobic bacteria, total coliforms and E. coli were performed according to methodologies described in the literature (Silva et al., 2017). For the counting of heterotrophic bacteria, the plating method was used in depth in Plate Count Agar (PCA), removing $1 \mathrm{~mL}$ aliquots of from the sample and performing successive deciduous dilutions in $9 \mathrm{~mL}$ of sterile saline solution up to $10^{3} .1 \mathrm{~mL}$ of each dilution was inoculated into sterile, properly identified plates and $20 \mathrm{~mL}$ of fused PCA were added. Plates were incubated at $35^{\circ} \mathrm{C}$ for 48 hours; after this time, the plates were read, determining the number of Colony Forming Units $(\mathrm{CFU}) / \mathrm{mL}$ of the sample.

For quantification of total coliforms and E. coli, Colilert ${ }^{\circledR}$ with Quanti-Tray ${ }^{\circledR} / 2000$ cartons was used, according to the manufacturer's instructions (IDEXX, 2016) and Silva et al. (2017). This system is based on the enzymatic methodology with the chromogenic substrate, being suitable for the determination of the most probable number of total coliforms and E. coli per $100 \mathrm{~mL}$ of water. The proposed method uses as reagents the defined substrates, namely ortho-nitro-phenyl-beta-Dgalactopyranoside (ONPG), which detects the B-D-galactosidase enzyme produced by total coliforms and 4-methylumbelliferyl-B-D-glucuronide (MUG), which detects the B-D-galactosidase enzyme produced by E. coli. In the latter case, blue fluorescence emission is observed during the reading, when the cards are placed under reading at $365 \mathrm{~nm}$ under ultraviolet light in dark environment, in the first case, the presence of total coliforms is evidenced by the development of yellow coloration in the solution of the card. Negative results for the test are denoted by the absence of staining after a period in an oven at $35^{\circ} \mathrm{C}$ for 24 hours. 
The quality parameters for the analyzes were based on Ordinance $n^{\circ} 5$ of 2017 annex XX of the Ministry of Health, a legal instrument that defines drinking water standards for human drinking water (Brazil, 2017).

Statistical Package for Social Sciences v.17 (SPSS Inc., Chicago, IL, 2008) was used for the statistical analysis of the results. The t-Pareto test was used to compare the results obtained in the two stages of the analysis. This test is appropriate for situation (an observation for each combination of the nominal values), interpreting the " $p$ ", which indicates if there is a statistical difference between the analyzed data $(p \leq 0.05)$.

\section{Results}

A high number of samples were found and they were not according to the legal standards in force in the first stage. This was brought to the attention of the person in charge of the general services of that Institution, who was instructed on the need for the correct hygiene of the drinking fountains, that is, washing with soap and water and disinfection with $70 \%$ alcohol. In addition, it was suggested to change filters of some equipment and to clean the reservoirs (water tanks) in some buildings.

A positive impact could be observed after the intervention. In the bacteriological research, a high non-compliance index was observed in the samples obtained in the first stage (rainy season), in which $65.3 \%$ of them were inadequate, with the parameters established by current legislation as the potability reference. Among the 32 drinking fountains with high counts of mesophilic aerobic heterotrophic bacteria, four presented contamination by total coliforms and E. coli. In the second stage (dry period) and after educational intervention and corrective measures, the failure was equal to $20.4 \%$ of the samples, with 10 points being reproved due to high rates in the count of mesophilic aerobic heterotrophic bacteria $(>500 \mathrm{CFU} / \mathrm{mL})$, and two due to contamination of total coliforms and E. coli (Figure 1).

Figure 1. Percentage of drinking fountains analyzed in the two stages of the study showing compliance or not with Normative Ordinance $n^{\circ} 5$ of 2017 annex XX, Ministry of Health, Brazil.

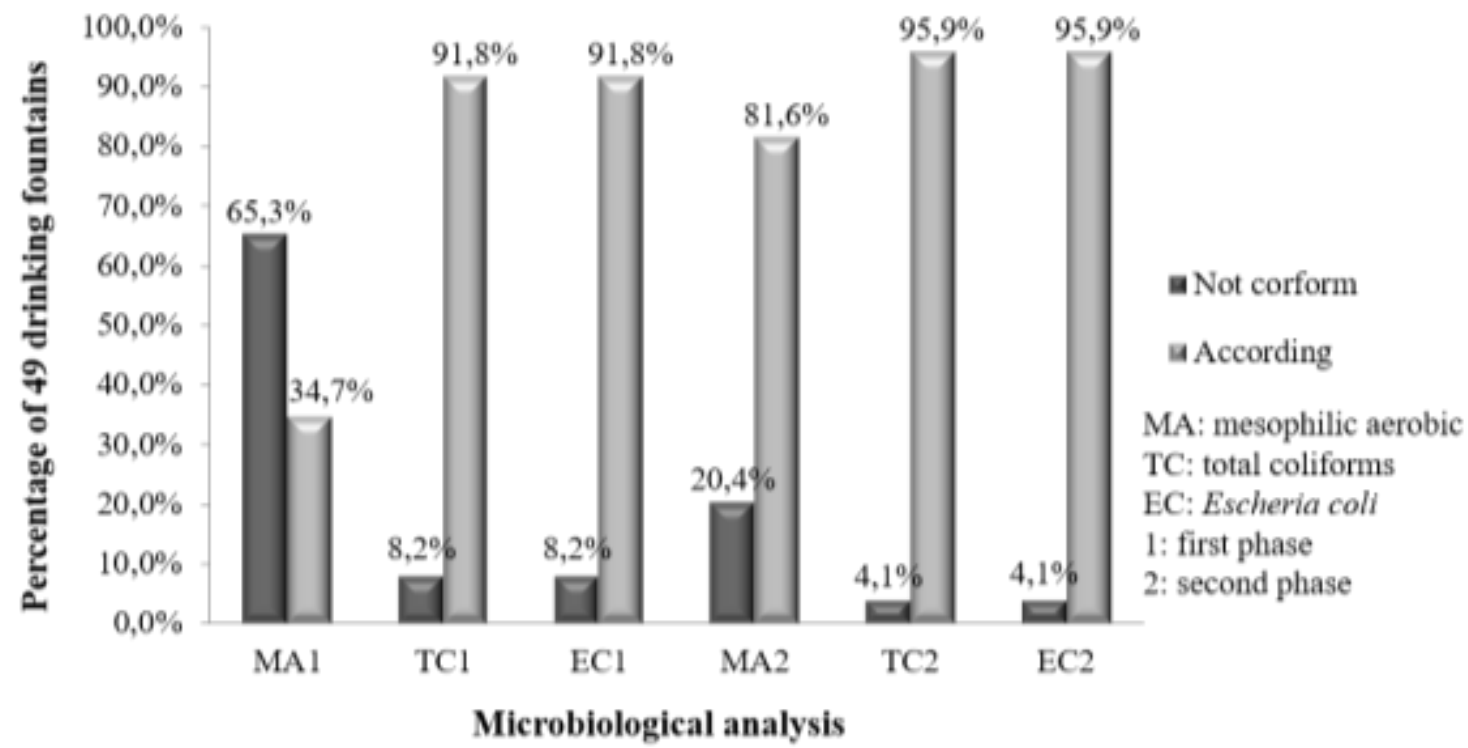

These results show that there was a reduction in the contamination of drinking fountains between the first and second phases with a drop of $65.3 \%$ of the points to $20.4 \%$ contaminated with mesophilic aerobic, a reduction of $68.8 \%$ between the contaminated points. In addition, contamination by coliforms and E. coli has also been cut in half.

Source: Authors. 
Regardless of the different climatic periods, a reduction of the non-compliance profile was observed for the results found in the bacteriological analyzes of total coliforms and E. coli, but without statistical significance ( $>0.05)$ between the two collection stages. On the other hand, when evaluating the results for mesophilic aerobic heterotrophic bacteria and for chemical analysis of chlorine, significant differences were evidenced $(\mathrm{p}<0.05)$. Thus, an improvement was observed in the compliance rates with the current legislation for the parameters heterotrophic mesophilic aerobic bacteria and chlorine residual.

Regarding the results of the $\mathrm{pH}$ analysis, all drinking fountains presented adequate values in the two study steps (Figure 2). In relation to residual chlorine content, in the first stage, $59.2 \%$ of the points showed absence of this compound, while in the second, this percentage decreased to $20.4 \%$ (Figure 2).

Regarding the hygienic conditions and conservation of the drinking fountains (presence or absence of dirt, rust and other impurities) observed macroscopically at the time of collection, most were in good condition (clean and well maintained) in both stages of the research, however, in the first stage, there was the presence of dirt at points 36 to 49 , which correspond to the buildings in which theoretical classes are taught, where there is a large circulation of people. Therefore, a correlation was found between inadequate hygiene conditions and the violation of drinking potability standards, since the above points were disapproved concomitantly in these two aspects.

According to the person in charge of the maintenance of the Institution's physical structure, an outsourced company carries out the cleaning of the water tanks every six months. Most of the reservoirs are made of high-density polyethylene (HDPE), except points 42 to 49 which are made of cement and points 6 and 7 which are made of asbestos. Even with the presence of covers, they can present cracks that facilitate the access of physical, chemical and biological contaminants. Thus, as observed by Pezente (2009), many water tanks are located near roofs and in places of difficult access, which further complicates the hygiene process.

On the other hand, when consulted about the drinking fountains in the institution, it was informed that the filter change does not occur frequently and it is only carried out upon request by the interested parties, subject to the availability of the product. In addition, there is no control of their expiration date, which indicates a certain negligence regarding the maintenance of the system. Regarding the pipes that distribute the water, they are all made of polyvinyl chloride (PVC) and, therefore, resistant to corrosion and likewise, do not undergo periodic maintenance.

The results found in this research were sent to the university's rectory with the suggestions for routine hygiene of the drinking fountains and periodic analyzes of water samples. Considering that water for human consumption can carry several substances (Campos, Franco, Abreu Filho, Bergamasco, \& Yamaguchi, 2017), it would be interesting, in future studies, to also correlate other parameters such as turbidity, suspended solids, temperature, electrical conductivity and metals analysis which were not performed at the time of the study as there was no availability of all necessary equipment and reagents. 
Figure 2. pH values and residual chlorine content found in steps 1 and 2 in the drinking fountains numbered 1 to 49.
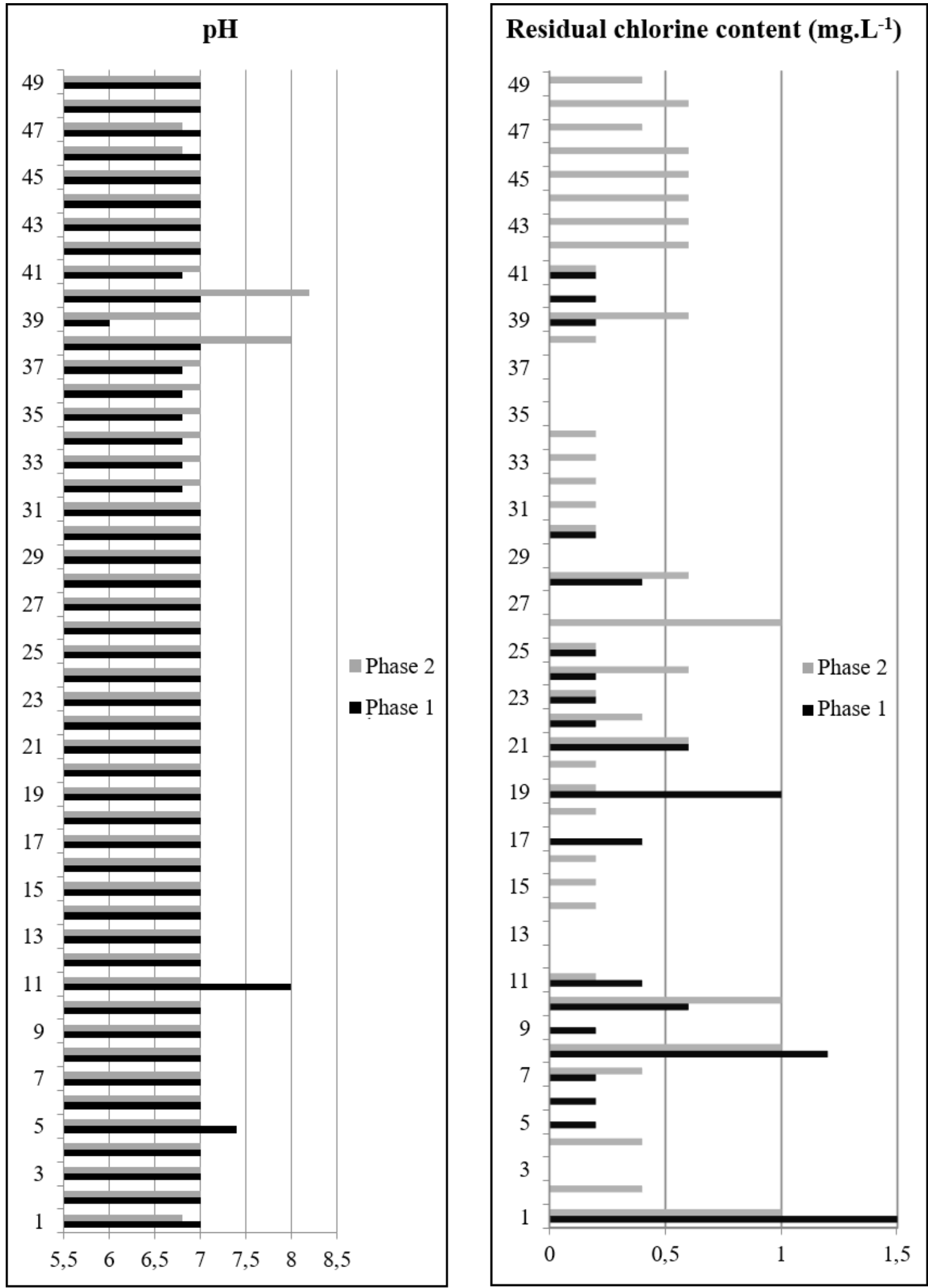

The $\mathrm{pH}$ values were in accordance with the specifications of norm $\mathrm{n}^{\circ} 5$ of 2017 (Brazil, 2017) and showed no differences ( $>$ 0.05). The number of fountains with residual chlorine increased between the first and second phases from $40.8 \%$ to $79.6 \%$.

Source: Authors. 


\section{Discussion}

The norms referring to the microbiological quality of water in Brazil define that that for consumption in the distribution system (reservoirs and network) must be free of E. coli, that is, absent in $100 \mathrm{~mL}$. In supply, from 20,000 inhabitants, the absence in $100 \mathrm{~mL}, 95 \%$ of those examined in the month, should be noted. For the count of mesophilic aerobic heterotrophic bacteria, these microorganisms must be below $500 \mathrm{CFU} / \mathrm{mL}$ (Brazil, 2017).

Brazil, a country with a tropical climate, has a remarkable thermal range, with stations with great disparities in relation to air humidity and rainfall (Picinin et al., 2013). Differently from what was observed in the second stage of the research presented, whose analyzes were carried out in the winter and early spring months, characterized by low temperatures and little rainfall, there was a higher frequency of contamination and non-conformities to the limits established in the current legislation, in the water samples collected during the summer and early autumn seasons - first stage.

These findings are in agreement with the observation of Castro et al. (2016), which the seasonal difference found for the higher count of mesophilic aerobic microorganisms in water samples from the rainy season than that observed during the dry season, to the temperature and humidity variations that impact on bacterial growth.

Another possibility is the increase in precipitation rates, a fact that can increase the amount of organic matter available for nutrition of the microorganisms, in addition to affecting color and turbidity. This fact indicates the necessity of a higher chlorine concentration in the water during the rainy season to obtain disinfection efficiency.

Finally, the microbiological contamination found in the first stage of the experiment can also be attributed to the lack of regularity between the exchange and maintenance of drinking fountain filters, which may lead to accumulation of bacteria and trigger diseases in the university community (Capistrano, Menezes, \& Oliveira, 2011).

This fact may compromise the safety or health of the population of the University, constituted by approximately 2000 people/day, including teachers, students, patients from the Dental Clinic and the Central Laboratory of Clinical Analyzes, a public constituted of children, the elderly and the immunosuppressed, which potentially use the drinking fountains present there and may expose themselves to pathogens carried by water.

Van der Spiegel, van der Fels-Klerx and Marvin (2012) reported that monitoring and early warning of food safety hazards are therefore very important to avoid the effects on human health. In this sense, the situation found in this research strengthens the current view that studies like this represent an important public health measure, since they signal the need for greater attention on the part of those responsible for these equipments at the University, in order to formulate a policy resolution, and promote the continuity surveillance of potability indicator parameters.

Comparing the results found in this work with the scientific literature on water quality in Higher Education Institutions in Brazil, it is possible to observe similarity with some authors, as described below.

It is known that the group of coliforms is responsible for most of the bacteria found in water (Barbosa et al., 2012). The most prevalent genera are Escherichia, Enterobacter, Citrobacter and Klebsiella with only the first being exclusively present in the intestinal tract of man and of warm-blooded animals and is eliminated by feces, a fact that makes it an indicator of fecal contamination (Schazmann et al., 2008; Siqueira \& Okura, 2005). Zulpo, Peretti, Ono and Garcia (2006) when analyzing the water consumed in the drinking fountains of the State University of the Midwest (Unicentro), noticed that four of the 47 samples ( $8.5 \%)$ were positive for total coliforms and one (2\%) for fecal coliforms.

Oliveira \& Terra (2004) performed the microbiological analysis of drinking water at the Faculdade de Medicina do Triângulo Mineiro and evidenced the presence of total coliforms in all collected samples. The authors also described that the devices supplied with water that came directly from the street, without going through reservoirs, had the lowest contamination rates. This is because in the hypotheses in which the water remains stationary for a longer time, there is a favor in the 
evaporation of chlorine and the formation of biofilms, which become continuous sources of contamination of the same, both in the distribution system and in the water tanks (LeChevallier, Welch, \& Smith, 1996; Silva Jr, 2014).

Pongeluppe et al., (2009), analyzing water from drinking fountains located in a Teaching Institution of Guarulhos-SP, found total coliforms in five of the nine samples studied $(55.5 \%)$ and attributed this result to the proximity of the installation of these devices to the bathrooms and to the frequency that they remain disconnected from the power grids, which would impair water cooling and increase the risk of microbial contamination and multiplication.

Neves, Coutinho, Ferreira, Souza and Fontenelle, (2016) carried out the microbiological water test of nine drinking fountains at the State University Vale do Acaraú in the municipality of Sobral - CE, during three semesters between the years 2013 and 2014. Regarding the total coliforms, in a universe of 27 samples, nine showed positive results, eight were contaminated by thermo tolerant coliforms. After biochemical analysis, these authors identified the presence of the Serratia marcescens, Proteus mirabllis and Klebsiella pneumoniae and attributed this contamination to the drinking fountains state of conservation.

Using the same methodology of this study, Tabalipa, Silva and Monteiro (2014) found that in a universe of ten drinking fountains of a Public Institution of Paraná, one presented a positive result for total coliforms. The authors concluded that this result did not indicate poor water quality, but a contamination from the plumbing system or in the drinking fountain, and emphasized the importance of filter cleaning.

However, in the evaluation of the water quality from 71 drinkers from the State University of Campinas, it was found that $81 \%$ were in a worrying situation due to the lack of replacement and maintenance of the filters. In addition, $8 \%$ of the devices did not have a filter and $73 \%$ were out of date. The authors of the study reported that the process of filtering water before its consumption is one of the many stages of its treatment, as well as those carried out at the states and distribution networks and therefore cannot be neglected (Capistrano et al., 2011).

When assessing the microbiological quality of drinking water of the drinking fountains from a university campus in Ipatinga, Minas Gerais, Barbosa, Lage and Badaró (2009) found values higher than $500 \mathrm{CFU} / \mathrm{mL}$ in the counts of heterotrophic bacteria in 20 drinkers $(90 \%)$. This percentage was higher than that observed in the first stage of this study $(65.3 \%)$.

Despite being part of the natural microflora of the water, the high density of these bacteria as well as what occurred in the first part of this study, is worrying and should be investigated, since they have secondary pathogenic potential and can cause damages to consumers' health, which makes their control essential (Sabioni \& Silva, 2006).

Another parameter investigated in the present research was the residual chlorine that is an important chemical used in the process of water disinfection (Brazil, 2017), because it causes cell damage due to its strong oxidative activity (Dodd, 2012). Current legislation recommends that the free residual chlorine content at any point in the supply system should be between 0.2 and $2 \mathrm{mg} . \mathrm{L}^{-1}$ (Brazil, 2017). In this study, the results ranged from 0 to $1.2 \mathrm{mg} . \mathrm{L}^{-1}$. The values below the recommended values revealed the inefficiency of the chlorination in some points, especially in those samples collected during the rainy season and can be related to the reaction between chlorine and the organic matter inside the water pipe or box (WHO, 2000); as well as the neutralization by activated carbon present in the interior of the filter that adsorbs this element, preventing its antimicrobial function (Carvalho, Fortunato, Vilela, \& Badaró, 2009).

This fact is worrying because without the protection of the chlorine and the degree of porosity PVC, which can reach $0.04 \mathrm{~mm}$, it makes susceptible the formation and development of biofilms in systems exposed at room temperature, especially after accumulation of dirt in the folds of the pipes. According to the National Sanitary Surveillance Agency, biofilms consist of a variety of Gram-negative and Gram-positive bacteria, difficult to eliminate and highly resistant to sanitization, due to the matrix formed (Brazil, 2013). 
In the present research, an increase in the number of samples with residual chlorine within the legal specifications was observed, from $40.82 \%$ to $75.51 \%$, between collection stages 1 and 2, respectively. This variation followed the bacteriological quality of the water between stages of the study, that is, it was verified a satisfactory increase from $34.7 \%$ and $79.6 \%$ between stages 1 and 2 , respectively.

In a study developed by Lemos, Rodrigues, Costa, Lemos and Severo (2013) in two schools A and B, it was found that the residual chlorine was below the legal specification in school A. The authors associated the result found at the distance of this school from the water treatment place, which would imply in a second necessary chlorination, carried out in a box very close to the school.

The distribution of the free and ionized forms of various chemical substances is dependent on the $\mathrm{pH}$ value of the medium, in addition, this parameter impacts on the degree of solubility of these substances (Brazil, 2006). Regarding the pH of water for human consumption, Normative Ordinance $\mathrm{n}^{\circ} 5$ of 2017 annex XX establishes that it should be in the range of 6.0 to 9.5 (Brazil, 2017). In this study, the values varied from 6.8 to 8.2, staying within the norms established by the aforementioned legislation.

These findings may have contributed to a greater disinfectant activity of residual chlorine, since it is advisable that the $\mathrm{pH}$ to be between 6.0 and 8.3. This is because in this interval the hypochlorous acid ( $\mathrm{HClO})$ is found in an appropriate percentage (35\% $\mathrm{HClO}$ available) for the process in question. Under these conditions, the dissociation of $\mathrm{HClO}$ in hypochlorite ion $(\mathrm{OCl})$ is reduced and allows a greater activity against microorganisms, besides inhibiting the formation of bacterial biofilms (Mélo, 2016; Yamaguchi, Cortez, Ottoni, \& Oyama, 2013).

These results can also contribute to the increase in the useful life of the drinking fountains and the pipes, by reduction of the oxidation. Under acid $\mathrm{pH}$ conditions for a prolonged period, despite positively influencing the increase in the residual chlorine disinfectant activity (Freitas, Brilhante, \& Almeida, 2001), the water can be corrosive to metals, cement surfaces and asbestos. In basic pH, they can generate incrustations in the materials and surfaces of pipes (Macedo, 2007). Thus, the pH of the water must be controlled to enable the equilibrium of the carbonates (Mélo, 2016).

Other studies report water samples with acceptable $\mathrm{pH}$ values. An example would be those presented by Pezente (2009) and Seco, Burgos and Pelayo (2012) who observed results from 7.15 to 7.5 and from 6.11 to 6.87, respectively. On the other hand, (Damiani et al., 2013) evaluated the physical and chemical quality of drinking fountains at the Federal University of Goiás, and verified that among the evaluated parameters, the $\mathrm{pH}$ did not fit the current norms because it presented average values of 5.05 and 0.5828 , in this order.

\section{Conclusion}

The results found demonstrate the existence of inadequate hygienic-sanitary conditions and the need for frequent monitoring of water quality. In addition, we verified the positive impact of educational intervention and the adoption of preventive and corrective measures, aiming at the safety of the consumer community.

Considering that water is essential for the maintenance of human life, it cannot pose health risks. Thus, in order to detect possible physical, chemical and / or biological changes early, it is suggested to continue the research with periodic monitoring of water obtained from drinking fountains involving similar analyzes related in that study and also of other parameters provided for in the current legislation (as fluorine, turbidity and color). For this reason, we encourage different educational institutions to develop projects on the same theme. Periodic monitoring favors the correction of failures (cleaning of reservoirs and drinking fountains), educational guidelines (cleaning staff and consumer population) and, consequently, the safety of users. 


\section{Acknowledgments}

This research was funded in part by UNIFAL-MG. The authors would like to thank PROEXT for the granted scholarship.

\section{References}

Andrade, F. S., Silva, A. M., Aride, P. H. R., \& Oliveira, A. T. (2016). Análise Físico-Química e da Microbiota da Água do Lago Macurany, Parintins, Amazonas. Biota Amazônia, 6(2), 132-134. https://doi.org/10.18561/2179-5746/biotaamazonia.v6n2p132-134

Antunes, A. C., Castro, M. C. F. M., \& Guarda, V. L. M. (2004). Influência da qualidade da água destinada ao consumo humano no estado nutricional de crianças com idades entre 3 e 6 anos, no município de Ouro Preto-MG. Alimentos e Nutrição Araraquara, 15(3), 221-226.

Araújo, T. M. ., Baraúna, A. C. ., \& Meneses, C. A. (2009). Identificação de Escherichia coli em água d ebebedouros e nos próprios aparelhos de quatro escolas públicas de Boa Vista, Roraima, Brasil. Anais Congresso de Pesquisa e Inovação Da Rede Norte Nordeste de Educação Tecnológica. Belém.

Barbosa, C. da C., Fernandes, A. P., Saraiva, G. K. V., Costa, F. E. de C., \& Loyola, A. B. A. T. (2012). Qualidade microbiológica da água consumida em bebedouros de uma unidade hospitalar no Sul de Minas. Revista Eletrônica Acervo Saúde, 4(1), 200-211. http://acervosaud.dominiotemporario.com/doc/artigo_017.pdf

Barbosa, D. A., Lage, M. M., \& Badaró, A. C. L. (2009). Qualidade microbiológica da água dos bebedouros de um campus universitário de Ipatinga, Minas Gerais. Nutrir Gerais - Revista Digital de Nutrição, 3(5), 505-517.

Brazil. (2006). Vigilância e controle da qualidade da água para consumo humano. Série B. Textos Básicos de Saúde. Brasília (DF).

Brazil. (2017). Portaria de consolidação $n^{\circ}$ 5. Anexo XX. Do controle e da vigilância da qualidade da água para consumo humano e seu padrão de potabilidade.

Brazil. (2013). Guia de Qualidade para Sistemas de Purificação de Água para Uso Farmacêutico.

Bunyavanich, S., Landrigan, C. P., McMichael, A. J., \& Epstein, P. R. (2003). The Impact of Climate Change on Child Health. Ambulatory Pediatrics, 3(1), 44-52. https://doi.org/10.1367/1539-4409(2003)003<0044:TIOCCO >2.0.CO;2

Campos, D. A. G., Franco, J. de M., Abreu Filho, B. A. de, Bergamasco, R., \& Yamaguchi, N. U. (2017). Avaliação da qualidade da água destinada ao consumo humano em instituição de ensino. Revista Da Universidade Vale Do Rio Verde, 15(1), 289-298. https://doi.org/10.5892/ruvrd.v15i1.3340

Capistrano, B. C., Menezes, E. M. de, \& Oliveira, H. E. de. (2011). Qualidade da água nos bebedouros da UNICAMP. Revista Ciências Do Ambient On-Line, 7(1), 24-27.

Carvalho, D. R., Fortunato, J. N., Vilela, A. F., \& Badaró, A. C. L. (2009). Avaliação da qualidade físico-química e microbiológica da água de um campus universitário de Ipatinga -MG. Nutrir Gerais - Revista Digital de Nutrição, 3(5), 417-427. http://www.unilestemg.br/nutrirgerais/downloads/artigos/5 _edicao/Artigo_QUALIDADE_MICROBIOLOGICA_DA_AGUA_DOS_BEBEDOUROS.pdf

Castro, R. D., Oliveira, L. G., Sant'Anna, F. M., Luiz, L. M. P., Sandes, S. H. C., Silva, C. I. F., \& Souza, M. R. (2016). Lactic acid microbiota identification in water, raw milk, endogenous starter culture, and fresh Minas artisanal cheese from the Campo das Vertentes region of Brazil during the dry and rainy seasons. Journal of Dairy Science, 99(8), 6086-6096. https://doi.org/10.3168/jds.2015-10579

Damiani, C., Soares, N. R., Ferreira, P. P., Fernandes, P. R., Nicolau, E. S., \& Silva, F. A. da. (2013). Avaliação física e química de água de bebedouros consumida por estudantes da UFG, Goiânia, GO. Higiene Alimentar, 27(216/217), 189-193.

Dodd, M. C. (2012). Potential impacts of disinfection processes on elimination and deactivation of antibiotic resistance genes during water and wastewater treatment. Journal of Environmental Monitoring, 14(7), 1754. https://doi.org/10.1039/c2em00006g

Freitas, M. B. de, Brilhante, O. M., \& Almeida, L. M. de. (2001). Importância da análise de água para a saúde pública em duas regiões do Estado do Rio de Janeiro: enfoque para coliformes fecais, nitrato e alumínio. Cadernos de Saúde Pública, 17(3), 651-660. https://doi.org/10.1590/S0102-311X2001000300019

Helbling, D. E., \& VanBriesen, J. M. (2007). Free chlorine demand and cell survival of microbial suspensions. Water Research, 41(19), 4424-4434. https://doi.org/10.1016/j.watres.2007.06.006

IDEXX, L. (2016). Colilert test. https://www.idexx.com/water/products/colilert.html

LeChevallier, M. W., Welch, N. J., \& Smith, D. B. (1996). Full-scale studies of factors related to coliform regrowth in drinking water. Applied and Environmental Microbiology, 62(7), 2201-2211. http://www.ncbi.nlm.nih.gov/pubmed/8779557

Lemos, E. E. R., Rodrigues, G. P., Costa, T. L., Lemos, L. M. R., \& Severo, L. S. (2013). Análises físico-química da água dos bebedouros e reservatórios das escolas municipais de Quixeramobim-CE. Revista Higiene Alimentar, 27, 31-33.

Macedo, J. A. B. de. (2007). Águas \& Águas (3ª). Belo Horizonte: CRQ-MG.

Mélo, R. A. (2016). Qualidade físico-química e microbiológica de água fornecida em bebedouros de escolas municipais em Cabedelo-PB (Universidade Estadual da Paraíba, Campina Grande, 2016). https://bdtd.ibict.br/vufind/Record/UEPB_4f8b33bc706fb1aa4016768fa36dd3ba

Michelina, A. de F., Bronharoa, T. M., Daréb, F., \& Ponsanoc, E. H. G. (2006). Qualidade microbiológica de águas de sistemas de abastecimento público da 
região de Araçatuba, SP. Revista Higiene Alimentar, 20(147), 90-95.

Neves, A. M., Coutinho, M. G. S., Ferreira, C. S., Souza, F. F. P., \& Fontenelle, R. O. S. (2016). Avaliação Microbiológica da Água consumida em Bebedouros da Universidade Estadual Vale do Acaraú, Sobral-CE. Higiene Alimentar, 30, 142.

Oliveira, A. C. S. de, \& Terra, A. P. S. (2004). Avaliação microbiológica das águas dos bebedouros do Campus I da Faculdade de Medicina do Triângulo Mineiro, em relação à presença de coliformes totais e fecais. Revista Da Sociedade Brasileira de Medicina Tropical, 37(3), 285-286. https://doi.org/10.1590/S0037-86822004000300017

Pezente, Á. W. (2009). Análise microbiológica, física e química da água dos bebedouros e torneiras consumida na E.E.B Timbé do Sul, localizada no centro do município de Timbé do Sul - SC (Universidade do Extremo Sul Catarinense - UNESC. Criciúma, SC.). http://www.bib.unesc.net/biblioteca/sumario/000041/00004183.pdf

Picinin, L. C. A., Cerqueira, M. M. O. P., Vargas, E. A., Lana, Â. M. Q., Toaldo, I. M., \& Bordignon-Luiz, M. T. (2013). Influence of climate conditions on aflatoxin M1 contamination in raw milk from Minas Gerais State, Brazil. Food Control, 31(2), 419-424. https://doi.org/10.1016/j.foodcont.2012.10.024

Pongeluppe, A. T., Oliveira, D. B. de, Silva, E. A. da, Aguileira, K. K., Zitei, V., \& Bastos, M. F. (2009). Avaliação de coliformes totais, fecais em bebedouros localizados em uma instituição de ensino de Guarulhos. Revista Saúde - UNG, 3(2), 5-9. http://revistas.ung.br/index.php/saude/article/viewArticle/257

Sabioni, J. G., \& Silva, I. T. da. (2006). Qualidade microbiológica de águas minerais comercializadas em Ouro Preto, MG. Revista Higiene Alimentar, 20(143), 72-77.

Schazmann, R. D., Menoncin, F., Elpo, E. R. S., \& Gomes, E. C. (2008). Avaliação da qualidade bacteriológica da água consumida no Campus III (Jardim Botânico) da Universidade Federal do Paraná, Curitiba, Brasil. Visão Acadêmica, 9(2), 65-70. https://doi.org/10.5380/acd.v9i2.14650

Schwenke, K. U., Spiehl, D., Krauße, M., Riedler, L., Ruppenthal, A., Villforth, K., \& Schwall, G. (2019). Analysis of free chlorine in aqueous solution at very low concentration with lateral flow tests. Scientific Reports, 9(1), 17212. https://doi.org/10.1038/s41598-019-53687-0

Seco, B. M. S., Burgos, T. D. N., \& Pelayo, J. S. (2012). Avaliação bacteriológica das águas de bebedouros do campus da Universidade Estadual de Londrina - PR. Semina: Ciências Biológicas e Da Saúde, 33(2), 193-200. https://doi.org/10.5433/1679-0367.2012v33n2p193

Silva, N. da, Junqueira, V. C. A., Silveira, N. F. de A., Taniwaki, M. H., Gomes, R., \& Okazaki, M. M. (2017). Manual de métodos de análises microbiológicas de alimentos e água ( $5^{\mathrm{a}}$ Ed; Blucher, Ed.). São Paulo - SP.

Silva Jr, E. A. da. (2014). Manual de Controle Higiênico Sanitário em serviços de alimentação (7 Ed). São Paulo: Editora Varela.

Siqueira, K. B., \& Okura, M. H. (2005). Enumeração de coliformes totais e coliformes termotolerantes em água de abastecimento e de minas. Revista Higiene Alimentar, 19(135), 285-286.

Soares, S. S., Arruda, P. N., Lobón, G. S., \& Scalize, P. S. (2016). Avaliação de métodos para determinação de cloro residual livre em águas de abastecimento público. Semina: Ciências Exatas e Tecnológicas, 37(1), 119. https://doi.org/10.5433/1679-0375.2016v37n1p119

Tabalipa, R., Silva, C. A. da, \& Monteiro, C. S. (2014). Análise microbiológica da água dos bebedouros de uma Instituição pública do Paraná. Higiene Alimentar, 28(238/239), 93-96.

van der Spiegel, M., van der Fels-Klerx, H. J., \& Marvin, H. J. P. (2012). Effects of climate change on food safety hazards in the dairy production chain. Food Research International, 46(1), 201-208. https://doi.org/10.1016/j.foodres.2011.12.011

WHO. (2000). Environmental Health Criteria 216: Environmental Health Criteria 216: Disinfectants and Disinfectant By-products. www.who.int/ipcs/publications/ehc/ehc_216/en

Yamaguchi, M. U., Cortez, L. E. R., Ottoni, L. C. C., \& Oyama, J. (2013). Qualidade microbiológica da âgua para consumo humano em instituição de ensino de Maringâ-PR. Mundo Da Saude, 37(3), 312-320.

Zulpo, D. L., Peretti, J., Ono, L. M., \& Garcia, J. L. (2006). Avaliação microbiológica da água consumida nos bebedouros da Universidade Estadual do Centro-Oeste, Guarapuava, Paraná, Brasil. Semina: Ciências Agrárias, 27(1), 107-110. https://doi.org/10.5433/1679-0359.2006v27n1p107 